\title{
PRODUCTIVE PERFORMANCE OF BUFFALO CALVES FED DIFFERENT LEVELS OF MILK REPLACER
}

\author{
G.F. Shahin; Mona E. Farag; E.A. El-Bltage; W.M. Wafa; M.A. El-Kisha and S.A. Ebrahim \\ Animal Production Research Institute, Ministry of Agriculture, Dokki, Giza, Egypt.
}

(Received 10/7/2018, Accepted 24/8/2018)

\section{SUMMARY}

$\mathrm{T}$ he objective of the present study was to evaluate the productive performance and economic efficiency for pre- and post-weaning buffalo calves fed milk replacer (MR) at levels of 9 , 10 and $11 \%$ of their body weight in the 1 st, 2nd and 3rd groups, respectively. Fifteen buffalo calves of average live body weight (LBW) $38.59 \pm 1.55 \mathrm{~kg}$ were chosen and separated from their dams within $2 \mathrm{~h}$ of birth. Calves were fed twice daily at the rate of $10 \%$ of their LBW on dam colostrum for the first three days and then the whole buffalo milk for seven days. Consecutively, calves were divided depending on their body weight into three groups with average body weight of $41.89 \pm 1.46 \mathrm{~kg}$ at the beginning of the experimental period (10 day initial age). The obtained results showed that increasing the level of milk replacer in the daily meal of suckling calves from $9 \%$ up to $11 \%$ of their body weight led to in parallel way to significant $(\mathrm{P}<0.05)$ decrease in solid feeds of starter, berseem hay $(\mathrm{BH})$ and rice straw $(\mathrm{RS})$. Calves in all experimental groups reached LBW over a range $(87.35-94.56 \mathrm{~kg})$ at weaning age $(15 \mathrm{wk})$, being the heaviest was occurred with G3, while calves in G1 showed the lightest ones, being significant differences among dietary treatments. Total and daily gain from initial-18 wk were significant higher $(\mathrm{P}<0.05)$ in $\mathrm{G} 2$ than those of $\mathrm{G} 1$, but being similar with those found with G3. The digestibility of all nutrients as well as the feeding values (TDN and DCP) did not significantly different among the dietary treatments (different levels of MR). On the other hand, Values of PCV, Hb and RBCs were the highest $(\mathrm{P}<0.05)$, while WBCs was the lowest $(\mathrm{P}<0.05)$ in $\mathrm{G} 2$. Concentrations of $\operatorname{IgG}, \operatorname{IgM}$ and $\operatorname{IgA}$ in blood serum were significant higher $(\mathrm{P}<0.05)$ with $\mathrm{G} 2$ than those of the other dietary treatments. Likewise, most blood metabolites were also markedly higher with G2 than those of G1 and G3 which have the low or high level of $\mathrm{MR}$, respectively. Comparatively the values of liver enzymes and the concentration of thyroid hormones (T4) for low level-MR (G1) were mostly significant $(\mathrm{P}<0.001)$ higher than those of mid MR level (G2) and insignificant higher than those of the high MR level (G3). It could be concluded that, using milk replacer at $10 \%$ of their live body weight had the improved growth performances of suckling buffalo calves as well as recognized highest economic feed efficiency as compared to those reared on the same milk replacer at levels of 9 or $11 \%$. This may help farmers to keep up and care of suckling buffalo calves and not sell it, and such regime could help to alleviate the problem of milk and beef shortage in Egypt.

Keywords: Buffalo calves, milk replacer, growth performance, blood biochemicals.

\section{INTRODUCTION}

Buffalo is playing a prominent role in rural livestock production providing milk and work draft force (Kumar et al., 2011). Egyptian buffalo represent about 1.8\% of the world buffalo population (FAO, 1998), which is more than 170 million head (FAO, 2004). In Egypt, buffalo milk contributes about $70 \%$ of domestic milk production (Nigm, 1996). Nutritional cost of milk production is high at all times of the year and this drain may interfere with the ability of farmers to the continuation of rearing suckling buffalo calves till weaning (3 months of age) on the whole buffaloes milk (WBM). However, several researchers have recognized that averages daily gain of calves at all times of the growing period is less affected by milk replacer compared with the whole cow milk (Moms and Wilton, 1976).

In young calves, rumen development depends on animal age and feed quality that is provided from liquid and solid feeds (Weary et al., 2009). Farmers forced to sell male calves at 40 days of age or earlier to save milk and avoid calf mortality to increase their income. Researchers used several feeding strategies which aimed to reduce the period from birth to weaning and as soon as possible transitioning from liquid to solid feed (Baldwin et al., 2004). Feeding dairy calves on milk replacer led to save milk for human consumption 


\section{Shahin et al.}

(Abdullah et al., 2013). Several authors reported that calves can reach early weaning and age at puberty by feeding more milk replacer (Cowles et al., 2006).

Solids intake by suckling calves is influenced by amount of suckled milk (Baker and Barker, 1978) and by availability and quality of solids intake (Wright and Russel, 1987). The range of correlation between level of milk consumption and weight gain among calves varies from 0.4 to 0.88 (Wyatt et al., 1977). Solids intake by suckling calves increases as lactation declines, and subsequently, applies greater pressure on the solids program (Fox et al., 1988). It has also been shown that solids intake per unit of BW before weaning is consistently increased for calves receiving low quantities of milk (Broesder et al., 1990) and that the consumption of milk decreases different solids intake (Baker et al., 1976). Few experiments have evaluated the performance of suckling calves when controlled amounts of milk with consuming solids, and the subsequent effect on the feedlot finishing phase. There were positive impact between reared dairy calves on milk replacer (MR) during the pre-weaning period and the long-term productivity of these calves (Soberon and Van Amburgh, 2012). In this respect, Bascom et al. (2007) reported that milk replacer had no effect on calf performance at weaning or post-weaning, while Kuehn et al., (1994) demonstrated a negative relationship between MR and starter consumption by calves. Weaning buffalo calves on solids intake at level of $2 \%$ (on dry matter basis) of their birth weight would be performed more efficient and economic (Salama and Mohy El-Deen, 1999). Using milk replacer in suckling buffalo calves resulted in lower feed cost per weight gain by $18.91 \%$ as compared to those fed whole milk (Aquino et al., 2008), without any effect on growth rate (Lorenz et al., 2011). Therefore, the objective of the present study was to evaluate digestibility, growth performance, hematological and blood biochemical parameters, immune response and economic efficiency pre- and post-weaning of buffalo calves fed milk replacer at different levels of their live body weight $(9,10$ and $11 \%)$.

\section{MATERIALS AND METHODS}

This study was conducted at El-Gemmeza, Animal Production Research Station, belonging to Animal Production Research Institute, Agricultural Research Center, Ministry of Agriculture, Egypt.

\section{Animals:}

Fifteen suckling male buffalo calves with an average live body weight (LBW) of $38.59 \pm 1.55 \mathrm{~kg}$ were chosen and separated from their dams within $2 \mathrm{~h}$ of birth and it were kept in an individual pens $(1.0 \times 1.5 \mathrm{~m})$ bedded with rice straw. Pens were designed to allow calves fed free access of their starter and berseem hay $(\mathrm{BH})$ as well as provided free access of water.

\section{Feeding system:}

Calves were fed twice daily at the rate of $10 \%$ of LBW on dam colostrum for the first three days and the whole buffalo milk daily for seven days. Consecutively, calves were divided depending on their weight into three groups with average body weight of $41.89 \pm 1.46 \mathrm{~kg}$ at the beginning of the experimental period. Calves in the experimental groups were fed milk replacer (MR) at levels of 9, 10 and $11 \%$ of their weight in the 1 st, 2nd and 3rd groups, respectively. Liquid milk replacer was prepared at each meal in steel buckets by mixing $0.18 \mathrm{~kg}$ of milk replacer in powder form with one liter of warm water $\left(60 \pm 2^{\circ} \mathrm{C}\right)$, then decreased to $38^{\circ} \mathrm{C}$ at feeding time. Calves were daily suckled the milk replacer 4 times at 8:00, 11:00, 18:00, and 23:00 $\mathrm{h}$ and given starter, 3rd cut $\mathrm{BH}$ and rice straw (RS) at free choice. Ingredients of milk replacer and starter as well as chemical composition on dry matter of feedstuffs are given in Tables (1 and 2).

At 12 wk of age, calves were gradually weaned by reducing the quarter amount of milk replacer every five days up to complete weaning at $15 \mathrm{wk}$ of age, while taking into account the presence of free access of starter and good $\mathrm{BH}$ as well as provided free access of drinking water. After weaning, all nutritional allowance of all groups was calculated according to the standard of Kearl (1982).

\section{Experimental procedures:}

\section{Growth performance parameters:}

Live body weight (LBW) and feed intake (milk replacer, starter, BH and RS) of calves were recorded at 10-d initial age, 12 - wk beginning of weaning, 15 - wk weaning age, and 18 - wk post-weaning, then total gain and daily weight gain as well as feed conversion were calculated at different phases of the experiment. 
Table (1): Ingredients of milk replacer powder and starter based on DM.

\begin{tabular}{|c|c|c|c|}
\hline Ingredients of milk replacer & $\%$ & Ingredients of starter & $\%$ \\
\hline Milk powder & 40 & Corn & 48 \\
\hline Sweet whey powder & 17 & Wheat bran & 15 \\
\hline Corn gluten meal (60\%) & 12 & Soybean meal (44\%) & 23 \\
\hline Coconut oil & 8 & Sunflower meal & 10 \\
\hline Vegetable fat & 7 & Limestone & 2 \\
\hline Soybean meal powder $(48 \%)$ & 6 & Salt & 1 \\
\hline Feed additives & 3.48 & Premix $^{1,2}$ & 1 \\
\hline Corn starch & 3 & & \\
\hline Corn flour & 3 & & \\
\hline Butyl hydroxyl toluene & 0.02 & & \\
\hline Premix $^{1,2}$ & 0.5 & & \\
\hline \multicolumn{4}{|c|}{$\begin{array}{l}{ }^{\mathrm{T}} \text { Provided (DM basis): } 5 \mathrm{mg} / \mathrm{kg} \text { of } \mathrm{Co}, 25 \mathrm{mg} / \mathrm{kg} \text { of } \mathrm{Cu}, 0.01 \% \mathrm{I}, 400 \mathrm{mg} / \mathrm{kg} \text { of } \mathrm{Fe}, 1 \% \mathrm{~K}, 0.60 \% \mathrm{Na}, 0.15 \% \mathrm{Mg}, 90 \mathrm{mg} / \mathrm{kg} \\
\text { of Mn, } 0.40 \% \mathrm{~S}, 0.02 \% \mathrm{Se}, 125 \mathrm{mg} / \mathrm{kg} \text { of } \mathrm{Zn} \text {. }\end{array}$} \\
\hline
\end{tabular}

Table (2): Chemical analysis (\% on DM basis) of milk replacer, starters, berseem hay and rice straw fed to calves.

\begin{tabular}{lcccc}
\hline Item & Milk replacer & Starter & Berseem hay (BH) & Rice straw (RS) \\
\hline DM & 97.50 & 88.98 & 87.39 & $88 . .25$ \\
Chemical composition (\%): & & & 81.87 \\
OM & 93.19 & 92.55 & 87.19 & 2.68 \\
CP & 28.00 & 19.24 & 13.22 & 38.72 \\
CF & 1.22 & 5.63 & 27.18 & 1.32 \\
EE & 8.50 & 2.97 & 0.67 & 39.15 \\
NFE & 55.47 & 64.71 & 46.12 & 18.13 \\
Ash & 6.81 & 7.45 & 12.81 & \\
\hline
\end{tabular}

\section{Body measurements:}

Body length (distance between the points of shoulder and point of pin bone), heart girth (circumference of the chest measured directly behind the front leg), withers height (distance from base of the front feet to the withers), and hip height (distance from base of the rear feet to hook bones) as body measurements of calves were estimated at initial, 12,15 and $18 \mathrm{wk}$ of age.

\section{Digestibility trails:}

Digestibility trials were conducted at the end of the experiment using three calves from each group. Fecal grape samples were taken from each calf at three successive days and composted for each animal to determine total tract apparent nutrients digestibilities using silica (McDonald et al., 2010) as an internal marker.

\section{Analytical procedures:}

\section{Chemical analyses of feedstuffs and feces:}

Representative samples of used feedstuffs, milk replacer and feces were analyzed for DM, CP, EE, CF and ash contents according to the AOAC (1995), while nitrogen free extract (NFE) was calculated by difference.

\section{Blood sampling:}

Blood samples were taken from all experimental calves from the jugular vein after three hours of morning feeding at initial, 12, 15 and $18 \mathrm{wk}$ of age in two test tubes (without and with anticoagulant). Hematological parameters, including packed cell volume (PCV), hemoglobin concentration (Hb), and count 
of red (RBCs) and white (WBCs) blood cells, were determined immediately in the whole blood of the 1st blood portion (with heparin). The 2 nd blood portion (without heparin) was allowed to clot and centrifuged at $3000 \mathrm{rpm}$ for $20 \mathrm{~min}$, then serum samples were separated and stored at $-20^{\circ} \mathrm{C}$ till analysis. Blood serum samples were analyzed for concentrations of total proteins (Henry, 1964), albumin (Doumas et al., 1971), glucose (Trinder, 1969), triglycerides (Mc Gowan et al., 1983), total cholesterol (Richmond, 1973), LDL and HDL density lipoproteins (Friedewald et al., 1972), total lipids (Zollner and Kirsch, 1962), urea (Bull et $a l .$, 1991), and creatinine (Bartles et al., 1972), while, globulin concentration was calculated by subtraction of serum albumin from total proteins concentration. Immunoglobulins ( $\mathrm{IgG}, \operatorname{IgM}$ and $\operatorname{IgA}$ ) concentrations in blood serum were determined with the quantitative ELISA (Bovine IgG, IgM, and IgA ELISA Quantitative kit, Bethyl laboratories, UK) according to Killingsworth and Savory (1972). Also, activity of asprtate (AST) and alanine (ALT) transaminases (Reitman and Frankel, 1957) and alkaline phosphatase (ALP, Young, 1995) were determined in blood serum. Lactate dehydrogenase (LDH) was determined colorimetericaly according to Cabaud et al. (1958). The concentration of triiodothyronine (T3) and thyroxin (T4) in blood serum were estimated using radioimmunoassay (RIA) commercial kits (Coat-A-Count@-TKT31) by Automatic Mini-Gamma Counter (LKB-1275) according to Saunders (1995).

\section{Statistical analysis:}

Data were analyzed according to SPSS (2010). The detected significant differences were performed at $(\mathrm{P}<0.05)$ by Duncan Multiple Range Test (Duncan, 1955).

\section{RESULTS AND DISCSSION}

\section{Feed intake:}

Data in Table (3) showed that daily total dry matter intake (TDMI) of calves did not significantly affected by dietary treatments over the first 12 wk-stage. It was clearly that as a results of increasing level of milk replacer in the daily meal of suckling calves from $9 \%$ up to $11 \%$ of their body weight, both DM intake from starter and $\mathrm{BH}$ significant $(\mathrm{P}<0.05)$ decreased gradually up to $11 \%$ milk replacer $(\mathrm{G} 3)$, that recorded the lowest quantities of both solid feeds. Likewise, over at $12-15$ wk of age, TDMI was significantly $(\mathrm{P}<0.05)$ decreased with increasing level of milk replacer in the daily meal also, that corresponding by the significant decreased in solid feeds of starter, BH and RS. It could be observed that the increases in milk replacer rate over the experimental groups during the first two stages of growth corresponded significantly for being reduction of the solid feed in the daily meal of suckling calves (starter, BH and RS). These results greatly might be due to that calves attained up to nearly physiological satisfaction of their nutritional requirements from milk replacer in particular with the highest level on the expense of solid feeds. Over the last period post weaning $(15-18$ wks), the total DM intake was significant $(\mathrm{P}<0.05)$ lower for calves in $\mathrm{G} 2$ and $\mathrm{G} 3$ than in G1. In fact, it is well known that CF content in the pre-weaning diet for suckling calves is potentially considering a key limiting factor to reach the right time for weaning calves. Considerably, the recommended content of $\mathrm{CF}$ in the starter could be greatly assistance of rapid development of the rumen which in turn reflected on the post-weaning growth rate. It is of interest to note that increasing level of milk replacer intake was associated with decreasing starter, berseem hay and rice straw intakes. It is well known that energy level is the main factor affecting feed intake. Based on the obtained results of feed intake from different feedstuffs, the high level of milk replacer (G3) had high nutritional values to meet energy requirements of suckling calves. Generally, solids feed intake is a limited factor affecting weaning period. Zicarelli (2006) reported that weaning of buffalo calves reached later due to lower intake capability that delays the intake of dry matter that in turn did not ensure adequate energy for calve growth. The utilization of starter diets for young calves at an early age is the best approach for improving both rumen papillae development and subsequent performance to attain a favorable growth rate (Bach et al., 2007). Also, NRC (2001) announced that calf starter showed be comparatively high in readily fermentable carbohydrates to support the fermentation required for suitable ruminal tissue growth. Experimental evidence indicates that intake of roughage, especially leguminous hay stimulates the development of the reticulo-rumen as well as increasing the weight, size and thickness of tissues and the growth of normal papillae (Warner and Flatt, 1965).

Recently, researchers have shown that enhancements in growth and feed efficiency can be acquired by feeding greater quantities of milk replacer or augmented concentration of nutrients in milk replacer (Brown 
et al., 2005). Moreover, ZHAO Heng-bo et al. (2007) indicated that the length, width of rumen papilla and its surface were significant increased in kids fed an alfalfa hay from 20 day old.

Table (3): Daily dry matter intake from different feedstuffs for buffalo calves during pre and postweaning intervals.

\begin{tabular}{lccc}
\hline Daily DM intake, kg/h & G1 & G2 & G3 \\
\hline Initial to 12 wk: & & & \\
Milk replacer & 0.83 & 0.98 & 1.14 \\
Starter & $0.43^{\mathrm{a}}$ & $0.31^{\mathrm{b}}$ & $0.25^{\mathrm{c}}$ \\
BH & $0.34^{\mathrm{a}}$ & $0.26^{\mathrm{b}}$ & $0.18^{\mathrm{c}}$ \\
RS & - & - & - \\
Total & 1.60 & 1.55 & 1.57 \\
12 to 15 wk: & & & \\
Milk replacer & 0.372 & 0.495 & 0.504 \\
Starter & $0.78^{\mathrm{a}}$ & $0.64^{\mathrm{b}}$ & $0.56^{\mathrm{c}}$ \\
BH & $0.51^{\mathrm{a}}$ & $0.38^{\mathrm{b}}$ & $0.25^{\mathrm{c}}$ \\
RS & $0.22^{\mathrm{a}}$ & $0.17^{\mathrm{b}}$ & $0.11^{\mathrm{c}}$ \\
Total & $1.882^{\mathrm{a}}$ & $1.685^{\mathrm{b}}$ & $1.424^{\mathrm{c}}$ \\
15 to wk: & & & \\
Starter & $1.26^{\mathrm{a}}$ & $1.14^{\mathrm{b}}$ & $1.12^{\mathrm{ab}}$ \\
BH & $0.68^{\mathrm{a}}$ & $0.64^{\mathrm{b}}$ & $0.58^{\mathrm{c}}$ \\
RS & $0.31^{\mathrm{a}}$ & $0.28^{\mathrm{b}}$ & $0.22^{\mathrm{c}}$ \\
Total & $2.25^{\mathrm{a}}$ & $2.06^{\mathrm{b}}$ & $1.92^{\mathrm{c}}$ \\
Total DM intake & $1.755^{\mathrm{a}}$ & $1.658^{\mathrm{b}}$ & $1.604^{\mathrm{b}}$ \\
\hline
\end{tabular}

Means denoted within the same row with different superscripts are significantly different at $P<0.05$.

\section{Growth performance:}

Data concerning growth performance parameters of calves pre and post-weaning stages are presented in Table (4). Results of LBW at 12, 15 and $18 \mathrm{wk}$ of age were significant $(\mathrm{P}<0.05)$ higher with the moderate MR- meal level (G2) and the high MR level (G3) than that of low MR level one (G1). These results are in consistent with the previous studies which was demonstrated greater growth for calves fed larger amounts of whole milk (Jasper and Weary, 2002) or milk replacers based on skim milk (Gerrits et al., 1996) or whey proteins (Diaz et al., 2001 and Brown et al., 2005). In addition, there was no significant differences between the moderate (G2) level of MR and the high (G3) level of MR regarding LBW at 18 wk of age, while at 12 and $15 \mathrm{wk}$ of age, calves in G3 was $(\mathrm{P}<0.05)$ significant higher than those of $\mathrm{G} 2$. Likewise both total gain and daily gain over either initial to $12 \mathrm{wk}$ of age or the whole experimental periods (Initial to $18 \mathrm{wk}$ ) were significant $(\mathrm{P}<0.05)$ higher with G2 and G3 than G1 one. Otherwise, over 12-15 wk of age and 15-18 wk of age the values of total weight gain and daily gain were significant $(\mathrm{P}<0.05)$ decreased. Regarding feed conversion, it was significant $(\mathrm{P}<0.05)$ better over the main suckling period that continued up to $12 \mathrm{wk}$ of age as well as the whole experimental period (0-18 wk), with greatest efficiencies observed for calves fed higher level of milk replacer (G3). On the other hand, over 12-15 wks of age, the high level of milk replacer (G3) seemed to be lesser in feed efficiency than the other treatments (G1 and G2). Such results might be due to the higher level of milk replacer (11\%) in the third experimental group that could be affect inversely on the intake of solid feeds (starter, BH and RS) and in turn affected unfavorably on growth of young calves and as well as on feed conversion as shown in Table (4). In relation to this point, high milk or milk replacer allocation to pre-ruminants retards rumen development. Therefore the recommended feeding strategy is to restrict milk or milk replacer feeding to promote early start on solid feeds. Moreover, earlier Huber et al. (1984) indicted that excess milk or milk replacer feeding delays starter intake and weaning age. Therefore, restricting milk or milk replacer to 8 to 10 percent of birth weight is recommended (NRC, 2001). Generally, Krishnamoorthy and Moran (2011) concluded that free access to clean drinking water and providing coarsely ground, fresh and palatable starter feed are the ways by which early intake of dry feeds can be promoted and thereby transition of pre-ruminants from milk replacers to solid feeds can be hastened. They were added that the transition of pre-ruminant feeding management from liquid milk to a diet based entirely on solid starter feeds (plus limited roughage) is one of the key management skills in rearing of young ruminants and this manual provides a good insight into how this can 
be best undertaken. These results are agreement with those reported by Brown et al. (2005) who showed that calves fed milk replacer (30\% CP and $16 \%$ fat on DM basis) at $2 \%$ their body weight was significant higher in their LBW (12 kg) more than those fed at $1 \%(21 \% \mathrm{CP}$ and $21 \%$ fat) of body weight at 8 wk of age. Diaz et al. (2001) determined that calf growth was directly related to intake of milk replacer. Blome et al. (2003) demonstrated that increasing of milk replacers fed at $1.5 \%$ of BW daily (DM basis) linearly increased LBW, total gain and daily gain.

Table (4): Productive performance of calves fed different levels of milk replacer at pre and postweaning intervals.

\begin{tabular}{lccc}
\hline Item & $\mathrm{G} 1$ & $\mathrm{G} 2$ & $\mathrm{G} 3$ \\
\hline Live body weight $(\mathrm{kg}):$ & & $35.80 \pm 1.90$ & $35.30 \pm 1.35$ \\
Initial & $36.40 \pm 2.12$ & $81.20 \pm 2.70^{\mathrm{b}}$ & $87.40 \pm 3.11^{\mathrm{a}}$ \\
At 12 wk of age ${ }^{(1)}$ & $75.80 \pm 4.17^{\mathrm{c}}$ & $91.82 \pm 5.12^{\mathrm{b}}$ & $94.56 \pm 5.46^{\mathrm{a}}$ \\
At 15 wk of age $(2)$ & $87.35 \pm 4.23^{\mathrm{c}}$ & $107.62 \pm 5.25^{\mathrm{a}}$ & $105.55 \pm 3.11^{\mathrm{a}}$ \\
At 18 wk of age $(3)$ & $99.70 \pm 3.71^{\mathrm{b}}$ & & \\
Total weight gain $(\mathrm{kg}):$ & & $45.40 \pm 2.12^{\mathrm{b}}$ & $52.10 \pm 2.32^{\mathrm{a}}$ \\
Initial $\sim 12$ wk of age & $39.40 \pm 1.60^{\mathrm{c}}$ & $10.62 \pm 1.26^{\mathrm{b}}$ & $7.16 \pm 0.89^{\mathrm{c}}$ \\
$12 \sim 15$ wk of age & $11.55 \pm 1.22^{\mathrm{a}}$ & $15.80 \pm 3.55^{\mathrm{a}}$ & $10.99 \pm 2.44^{\mathrm{c}}$ \\
$15 \sim 18$ wk of age & $12.35 \pm 2.33^{\mathrm{b}}$ & $71.82 \pm 5.65^{\mathrm{a}}$ & $70.25 \pm 6.11^{\mathrm{a}}$ \\
Initial $\sim 18$ wk of age & $63.30 \pm 4.87^{\mathrm{b}}$ & & \\
Daily gain (kg/d): & & $0.540 \pm 0.07^{\mathrm{b}}$ & $0.620 \pm 0.08^{\mathrm{a}}$ \\
Initial $\sim 12$ wk of age & $0.469 \pm 0.04^{\mathrm{c}}$ & $0.752 \pm 0.08^{\mathrm{a}}$ & $0.341 \pm 0.09^{\mathrm{c}}$ \\
$12 \sim 15$ wk of age & $0.550 \pm 0.07^{\mathrm{a}}$ & $0.570 \pm 0.06^{\mathrm{a}}$ & $0.523 \pm 0.07^{\mathrm{c}}$ \\
$15 \sim 18$ wk of age & $0.588 \pm 0.08^{\mathrm{b}}$ & & $0.558 \pm 0.06^{\mathrm{a}}$ \\
Initial $\sim 18$ wk of age & $0.502 \pm 0.04^{\mathrm{b}}$ & $2.870^{\mathrm{b}}$ & \\
Feed conversion $(\mathrm{kg} \mathrm{DM} \mathrm{intake/kg} \mathrm{gain):}$ & $3.330^{\mathrm{b}}$ & $2.500^{\mathrm{c}}$ \\
Initial $\sim 12$ wk of age & $3.410^{\mathrm{a}}$ & $2.739^{\mathrm{b}}$ & $4.176^{\mathrm{a}}$ \\
$12 \sim 15$ wk of age & $3.422^{\mathrm{b}}$ & $2.909^{\mathrm{b}}$ & $3.671^{\mathrm{a}}$ \\
$15 \sim 18$ wk of age & $3.827^{\mathrm{a}}$ & & $2.875^{\mathrm{b}}$ \\
$0 \sim 18$ wk of age & $3.496^{\mathrm{a}}$ & &
\end{tabular}

(1): Beginning of weaning. (2): End of weaning. (3): Post-weaning.

\section{Body measurements:}

Results in Table (5) showed that heart girth was significantly $(\mathrm{P}<0.05)$ recorded the highest values in $\mathrm{G} 3$, followed by G2 and the lowest values being associated with G1. Also, body length, wither height and hip height were significant higher for G2 and G3 compared with G1. It is of interest to note that all body measurements are in harmony with LBW of buffalo calves in experimental groups. Similar to the present results in buffalo calves, Bartlett et al. (2006) noted that body length, heart girth, wither height were greater for Holstein calves fed at $1.75 \%$ of BW than those fed $1.25 \%$ of BW of milk replacer.

Also, Brown et al. (2005) found that calves fed milk replacer at $10 \%$ of their body weight increased body length, withers height and hip height compared with those fed low level (8\% of body weight).

\section{Digestibility and feeding values:}

Data in Table (6) showed that the differences respecting all nutrients digestibilities and feeding values as TDN and DCP among the experimental groups, were not significant. The digestibility values of most nutrients for G1 were slightly higher than those of G2 and G3, while the slightly lower values were recorded with G3- diet. These results might be due to somewhat differences in feed intake during pre-weaning period where animal groups given different MR levels. In more explanation probably due to that animals on G1 received the low level MR- meal that also corresponding by the significant increased in solid feeds of starter, $\mathrm{BH}$ and RS and therefore increased of $\mathrm{CF} \%$ content, being enhancement of rapid development of the rumen, which is reflected positively on the post-weaning ruminal function and consequently significant growth performance for calves. Additionally, calves received solid feeds at the second week of calving enhanced progressively its acceptability to consume the solid feeds offered during the whole suckling periods. This 
suggests that the solid feed may have a long retention time in the rumen, and thereby small quantity of feed entering the rumen at each meal (Bhatti et al., 2008), allowing for a more complete degradation by microorganisms. Importantly, the duration and the rate of ingested milk or milk replacer by suckling calves during the early stage after calving considerably can be affect on the degree of rumen development at weaning time and in turn being affect positively or negatively on nutrients digestibilities of the solid feed meal, throughout what well known as carry over effect at after weaning phases. Concerning feeding values which expressed as TDN, it could be noticed that animals in G1 recorded insignificant higher values than that of G2 and G3. While the lowest one was recorded for G2, with no significant difference. This may be due to the relatively differences in development of rumen and this is reflected on all nutrients digestibilities in the post-weaning stage.

Table (5): Some body measurements of buffalo calves fed different experimental rations at pre and post-weaning intervals.

\begin{tabular}{|c|c|c|c|}
\hline Item & G1 & $\mathrm{G} 2$ & G3 \\
\hline \multicolumn{4}{|l|}{ Body length, cm } \\
\hline Initial age & $57.5 \pm 1.82$ & $59.4 \pm 2.48$ & $58.2 \pm 1.28$ \\
\hline At 12 wk of age & $69.8 \pm 1.16^{\mathrm{b}}$ & $76.2 \pm 2.47^{\mathrm{a}}$ & $77.8 \pm 1.16^{\mathrm{a}}$ \\
\hline At 15 wk of age & $73.8 \pm 1.53^{\mathrm{b}}$ & $80.8 \pm 1.66^{\mathrm{a}}$ & $80.2 \pm 1.71^{\mathrm{a}}$ \\
\hline At 18 wk of age & $79.7 \pm 1.41^{\mathrm{b}}$ & $86.9 \pm 2.33^{\mathrm{a}}$ & $84.5 \pm 2.22^{\mathrm{a}}$ \\
\hline \multicolumn{4}{|l|}{ Heart girth, $\mathrm{cm}$} \\
\hline Initial age & $78.8 \pm 1.39$ & $79.2 \pm 2.56$ & $79.6 \pm 1.96$ \\
\hline At $12 \mathrm{wk}$ of age & $85.8 \pm 1.63^{c}$ & $92.1 \pm 2.10^{\mathrm{b}}$ & $98.4 \pm 2.84^{\mathrm{a}}$ \\
\hline At $15 \mathrm{wk}$ of age & $89.4 \pm 1.86^{\mathrm{c}}$ & $95.4 \pm 2.36^{\mathrm{b}}$ & $100.9 \pm 2.44^{\mathrm{a}}$ \\
\hline At 18 wk of age & $93.2 \pm 2.44^{\mathrm{c}}$ & $99.5 \pm 5.65^{\mathrm{b}}$ & $103.5 \pm 2.41^{\mathrm{a}}$ \\
\hline \multicolumn{4}{|l|}{ Wither height, $\mathrm{cm}$} \\
\hline Initial age & $62.4 \pm 1.03$ & $64.0 \pm 1.73$ & $63.3 \pm 1.68$ \\
\hline At $12 \mathrm{wk}$ of age & $71.2 \pm 1.20^{\mathrm{b}}$ & $68.6 \pm 1.36^{\mathrm{b}}$ & $76.2 \pm 1.58^{\mathrm{a}}$ \\
\hline At 15 wk of age & $74.6 \pm 1.42^{\mathrm{b}}$ & $76.0 \pm 1.58^{\mathrm{ab}}$ & $79.4 \pm 2.11^{\mathrm{a}}$ \\
\hline At 18 wk of age & $78.3 \pm 2.40^{\mathrm{b}}$ & $82.4 \pm 1.93^{\mathrm{a}}$ & $83.0 \pm 1.86^{\mathrm{a}}$ \\
\hline \multicolumn{4}{|l|}{ Hip height, $\mathrm{cm}$} \\
\hline Initial age & $66.6 \pm 1.03$ & $66.8 \pm 1.28$ & $67.4 \pm 1.43$ \\
\hline At 12 wk of age & $67.2 \pm 1.20^{\mathrm{b}}$ & $81.4 \pm 1.21^{\mathrm{a}}$ & $82.8 \pm 1.58^{\mathrm{a}}$ \\
\hline At 15 wk of age & $79.9 \pm 2.12^{\mathrm{b}}$ & $84.8 \pm 2.11^{\mathrm{a}}$ & $86.1 \pm 2.10^{\mathrm{a}}$ \\
\hline At 18 wk of age & $83.8 \pm 3.24^{\mathrm{b}}$ & $88.6 \pm 2.33^{\mathrm{a}}$ & $89.7 \pm 1.86^{\mathrm{a}}$ \\
\hline
\end{tabular}

Means denoted within the same row with different superscripts are significantly different at $P<0.05$.

Table (6): Effect of milk replacer levels in daily meal of suckling calves on nutrients digestibilities at 18 weeks of age.

\begin{tabular}{lccc}
\hline Item & G1 & G2 & G3 \\
\hline Nutrient digestibility (\%) & & & \\
DM & $66.33 \pm 2.46$ & $65.91 \pm 3.11$ & $65.14 \pm 2.88$ \\
CP & $67.98 \pm 1.96$ & $68.26 \pm 2.34$ & $67.67 \pm 2.27$ \\
CF & $52.59 \pm 1.34$ & $51.02 \pm 1.11$ & $50.39 \pm 1.22$ \\
EE & $69.83 \pm 2.33$ & $69.51 \pm 1.96$ & $68.72 \pm 2.07$ \\
NFE & $74.88 \pm 2.76$ & $73.66 \pm 2.59$ & $73.59 \pm 2.31$ \\
Feeding values (\%) & & & \\
TDN & 63.74 & 62.93 & 63.05 \\
DCP & 10.30 & 10.33 & 10.50 \\
\hline
\end{tabular}

Concerning feeding values which expressed as DCP, it showed that no significant difference among treatments. These results are in good agreement with the findings of Bhatti et al. (2012) who reported that animals fed high level of milk, skim or milk replacer were not affected of all nutrients digestibilities. 


\section{Shahin et al.}

\section{Blood parameters:}

\section{Hematological parameters and immunoglobulin concentrations:}

Hematological parameters including packed cell volume (PCV), hemoglobin concentration $(\mathrm{Hb})$ and count of red blood cells (RBCs) were significantly $(\mathrm{P}<0.05)$ higher, while white blood cells $(\mathrm{WBCs})$ count was significantly $(\mathrm{P}<0.05)$ lower in calves of $\mathrm{G} 2$ as compared with those of $\mathrm{G} 3$ and $\mathrm{G} 1$. It is of interest to note that all hematological parameter values of calves in all experimental groups fed different levels of milk replacer seemed to be in normal range that reported for buffalo calves by Niaz et al. (2000) who indicated good health status of buffalo calves fed 8 or $10 \%$ of live body weight of milk replacer. Mostly all hematological parameters significantly $(\mathrm{P}<0.05)$ increased by advancing calf age up to weaning at 15 wks of age, then showed insignificant change till $18 \mathrm{wk}$ of age. Analysis of variance revealed that the effect of interaction between dietary treatments and age of calves were significant $(\mathrm{P}<0.05)$ for PCV and WBCs count $(\mathrm{P}<0.001)$. On the other hand, values of $\mathrm{PCV}, \mathrm{Hb}$ and RBCs were increase in $\mathrm{G} 2$ and slightly increase in G3 versus slight reduction in G1 and the values of these items also almostly significant increased with advancing calve age. However, the count of WBCs seemed to be significant lower in G2, than that of G3 and G1 and mostly un affected by calve age (Table 7). These results are in good agreement with those obtained by Harvey (1997) who reported clear reduction in hematological parameters in first days of life, which may be attributed to feeding calves on colostrum, which increase the plasma volume by its osmotic effect. In this respect, Hulbert et al. (2014) showed increase in concentration of $\mathrm{Hb}$, hematocrit value and count of WBCs from birth till 7 weeks of age for Holstein calves fed on milk replacer compared with natural milk or pasteurized milk.

Immunoglobulins concentration, including $\operatorname{IgG}, \operatorname{IgM}$ and $\operatorname{IgA}$, in blood serum of buffalo calves were significantly $(\mathrm{P}<0.05)$ higher in $\mathrm{G} 2$ than those in $\mathrm{G} 3$ or $\mathrm{G} 1$, but only IgG concentration was significantly $(\mathrm{P}<0.05)$ higher in $\mathrm{G} 3$ than that in $\mathrm{G} 1$. As affected by calf age, IgG concentration gradually reduced by age progress, being significantly $(\mathrm{P}<0.05)$ the highest at initial age, moderate at weaning $(15 \mathrm{wk}$ of age $)$ and the lowest at $18 \mathrm{wk}$ of age (post-weaning). On the other hand, concentration of both $\operatorname{IgM}$ and $\operatorname{IgA}$ showed almostly insignificant differences among different ages of calves, being the values at weaning age (15 wk) were significant higher than those of most other ages. It is of interest to note that the effect of interaction between level of milk replacer and calf age was significant for $\operatorname{IgG}(\mathrm{P}<0.01)$ and $\operatorname{IgM}(\mathrm{P}<0.05)$. According to immunoglobulin concentration in Table (7), feeding calves on milk replacer at a level of $10 \%$ of LBW (G2) enhanced calf immunity, in term of increasing I IgG, gM and IgA. In this way, Foote et al. (2004) suggested that the quantity and quality of milk replacer fed to dairy calves may have limited improvement in immune response compared with natural milk. Overall, the high immunoglobulin concentrations in buffalo calves of $\mathrm{G} 2$, this might be due to increasing concentration of total proteins and its fractions and good healthy condition of calves.

The observed remarkable reduction in IgG concentration by age progressing might be attributed to that calves are born without fully mature immune system and some authors indicated that presence of $\geq 10 \mathrm{mg}$ $\mathrm{IgG} / \mathrm{ml}$ in blood of calves is necessary for successful immunity response in the first few days of age (Logue and Mayne, 2014). In good agreement with the present results, Ježek et al. (2012) found marked reduction in concentrations of IgG blood for calves starting immediately after birth up to four weeks of age. In contrast to the present results, the same author observed decrease in $\operatorname{IgM}$ and $\operatorname{IgA}$ concentrations in blood of dairy calves from birth till one month of age.

\section{Concentration of some blood metabolites:}

Data in Table $(8)$ revealed significant $(\mathrm{P}<0.05)$ effect of milk replacer level on concentrations of total proteins (TP), globulin (GL), glucose (Glu), triglycerides (TG), LDL, HDL and total lipids (TL) in blood serum of buffalo calves, being higher $(\mathrm{P}<0.05)$ in $\mathrm{G} 2$ as compared to those of $\mathrm{G} 1$ and G3. However, albumin (AL), total cholesterol $(\mathrm{TCH})$, urea $(\mathrm{U})$ and creatinine $(\mathrm{Cr})$ concentrations did not affected.

Blood TP and AL concentrations showed gradually significant $(\mathrm{P}<0.05)$ increase with advancing calve age, while Glu, TG, TCH, LDL, HDL and TL concentrations significantly $(\mathrm{P}<0.05)$ higher at initial age compared with other ages. However, Gl, $\mathrm{U}$ and $\mathrm{Cr}$ concentrations were not affected by calf age. It is worth noting that the effect of interaction between milk replacer level and calf age was significant only for lipid profile, including LDL, HDL and TL concentrations. In this respect, concentration of LDL, HDL and TL showed higher rate of increase in G2 than those of G1 and G3 (Table 8). 
Egyptian J. Nutrition and Feeds (2018)

Table (7). 
Shahin et al.

Table (8). 
The presented results are in agreement with the findings obtained by Quigley et al. (2006) who indicated positive correlation between milk replacer level and blood total proteins and glucose in bovine calves. Also, the present results of AL and lipid profile are in agreement with those reported by Lee et al. (2008) for calves fed milk replacers. On the other hand, Blome et al. (2003) reported that plasma urea N concentration increased linearly with increasing of $\mathrm{CP}$ in the diets.

It is of interest to note that, increasing concentration of GLU, triglycerides, total cholesterol, LDL, HDL and total lipids in blood of buffalo at $15 \mathrm{wks}$ of age was attributed to the reduce in milk replacer supply during weaning period, then its concentrations being less by advancing age up to 18 wks. These results are in agreement with those obtained by Lee et al. (2008). Contrary, Smith et al. (2002) observed that calves blood urea concentration was decline with advancing age to post-weaning. Concerning Glu concentration, it could be noticed that slight decreased of its value with advancing age up to 18-wks after weaning and such status may be due to the shift into glucose as primary source of energy replacing to lactose in milk replacer. Also, the reduction in blood glucose concentration from birth till $18 \mathrm{wk}$. are an agree with Lee et al., (2008) who found that serum glucose was reduced with advancing age of calves.

\section{Enzyme activities and thyroid hormones:}

Data in Table (9) revealed that activities of aspartate transaminase (AST) and alkaline phosphatase (ALP) in blood serum of calves was significantly $(\mathrm{P}<0.05)$ higher with $\mathrm{G} 1$ compared with the other treatments. However, activities of alanine transaminase (ALT) and lactate-dehydrogenase (LDH) was significantly $(\mathrm{P}<0.05)$ lower in $\mathrm{G} 2$ than those of the other treatments. It was observed significant $(\mathrm{P}<0.05)$ reduction in AST and ALP activities with advancing age, while ALT and LDH activities did not significantly affected by calf age. The interaction effect between dietary treatments and age of calves were significant for activities of AST, ALT $(\mathrm{P}<0.05)$ and ALP $(\mathrm{P}<0.001)$, reflecting the highest rate of decrease in activities of AST and ALP in G2 as well as slight decrease in ALT activity as compared with other treatments by advancing calves age.

Despite the differences in enzyme activities as affected by dietary treatments and age of calves, its values are within the normal range of buffalo calves (Abd Ellah et al., 2014), reflecting normal liver function of calves in all groups. Similar results of AST and ALT activities were obtained on lambs fed different levels of milk replacer (Yang et al., 2015). Concentration of $\mathrm{T}_{3}$ was not significantly affected by dietary treatments and calf age or their interaction. However, $\mathrm{T}_{4}$ concentration was significantly $(\mathrm{P}<0.05)$ lower in $\mathrm{G} 2$ than that of other treatments, but, showing insignificant changes by advancing calve age. The effect of interaction between dietary treatments and calf age was significant $(\mathrm{P}<0.001)$ respecting $\mathrm{T} 4$ concentration, reflecting marked decrease in G2 (Table 9). These results are in agreement with those obtained by Hammon and Blum (1998) who concluded that calves (Simmental Red Holstein, Braunvieh Brown Swiss, and Holstein Friesian) fed different amounts (fed twice daily at the rate of 5 or $10 \%$ body weight/meal) of colostrums or a commercial milk replacer appeared to be the concentration of $\mathrm{T}_{3}$ was not affected by dietary treatments.

Table (9): Some enzyme activities and concentration of thyroid hormones in blood serum of calves as affected by dietary treatments and its age.

\begin{tabular}{|c|c|c|c|c|c|c|}
\hline \multirow{2}{*}{ Item } & \multicolumn{4}{|c|}{ Enzyme activity } & \multicolumn{2}{|c|}{ Thyroid hormones } \\
\hline & AST (U/l) & ALT (U/l) & ALP (U/1) & LDH $(g / l)$ & $\left.\mathrm{T}_{3} \mathrm{nmol} / \mathrm{l}\right)$ & $\mathrm{T}_{4}(\mu \mathrm{g} / \mathrm{dl})$ \\
\hline \multicolumn{7}{|c|}{ Effect of milk replacer level (L): } \\
\hline G1 & $50.80 \pm 0.50^{\mathrm{a}}$ & $16.86 \pm 0.20^{\mathrm{a}}$ & $95.90 \pm 1.53^{\mathrm{a}}$ & $715.05 \pm 23.61^{\mathrm{a}}$ & $3.03 \pm 0.04$ & $4.38 \pm 0.04^{\mathrm{a}}$ \\
\hline $\mathrm{G} 2$ & $46.40 \pm 0.80^{\mathrm{c}}$ & $15.30 \pm 0.26^{\mathrm{b}}$ & $83.96 \pm 2.92^{\mathrm{c}}$ & $626.50 \pm 25.63^{\mathrm{b}}$ & $2.95 \pm 0.04$ & $4.13 \pm 0.03^{b}$ \\
\hline G3 & $49.05 \pm 0.55^{\mathrm{b}}$ & $16.37 \pm 0.19^{\mathrm{a}}$ & $89.82 \pm 2.04^{\mathrm{b}}$ & $712.80 \pm 19.14^{\mathrm{a}}$ & $2.94 \pm 0.03$ & $4.35 \pm 0.03^{\mathrm{a}}$ \\
\hline \multicolumn{7}{|c|}{ Effect of calf age $(A)$ : } \\
\hline Initial & $49.80 \pm 0.52^{\mathrm{a}}$ & $16.46 \pm 0.23$ & $100.84 \pm 1.45^{\mathrm{a}}$ & $698.33 \pm 27.51$ & $3.05 \pm 0.06$ & $4.23 \pm 0.03$ \\
\hline At $12 \mathrm{wk}$ & $50.40 \pm 0.70^{\mathrm{a}}$ & $16.28 \pm 0.27$ & $93.16 \pm 2.07^{\mathrm{b}}$ & $707.00 \pm 24.84$ & $3.01 \pm 0.05$ & $4.34 \pm 0.06$ \\
\hline At $15 \mathrm{wk}$ & $48.00 \pm 0.94^{\mathrm{b}}$ & $15.87 \pm 0.29$ & $83.33 \pm 2.72^{c}$ & $667.53 \pm 29.72$ & $2.92 \pm 0.04$ & $4.32 \pm 0.05$ \\
\hline At $18 \mathrm{wk}$ & $46.80 \pm 0.94^{\mathrm{b}}$ & $16.11 \pm 0.41$ & $82.29 \pm 1.95^{\mathrm{c}}$ & $666.27 \pm 31.54$ & $2.90 \pm 0.03$ & $4.23 \pm 0.06$ \\
\hline \multicolumn{7}{|c|}{ Effect of interaction ( $\mathrm{L} \times \mathrm{A})$ : } \\
\hline P-value & $0.038^{*}$ & $0.033^{*}$ & $0.000 * * *$ & 0.852 & 0.064 & $0.001 * * *$ \\
\hline
\end{tabular}




\section{Economic feed efficiency:}

Although the reduction in starter, BH and RS intakes, daily feed cost increased by increasing milk replacer intake in G2 and G3 as compared to G1. On the other hand, increasing daily gain of calves in G2 and G3 as compared to G1 resulted in increasing the return of G2 and G3 compared with G1. These results indicated that economic feed efficiency of calves was the highest for G2 compared with other treatments (Table 10).

Accordingly, rearing buffalo calves on milk replacer at a level of $10 \%$ of their live body weight had the highest economic feed efficiency as compared to those reared 9 or $11 \%$ where this finding could be reflecting favorably on improvement of productive performance after weaning along the productive live of dairy and beef animals. These findings are in agreement with the results of Lee et al. (2008) and Soberon and Van Amburgh (2012) who reported that the different levels of milk replacer (18- 20\% CP and 10- 15\% fat on DM basis) reduced the feeding cost of suckling dairy calves during the first three months of age.

Table (10): Economic feed efficiency (\%) of buffalo calves in different experimental groups.

\begin{tabular}{lccc}
\hline Item & $\mathrm{G} 1$ & $\mathrm{G} 2$ & $\mathrm{G} 3$ \\
\hline Av. daily milk replacer intake (kg) & 0.738 & 0.883 & 1.013 \\
Cost of milk replacer (L.E./d) & 13.28 & 15.89 & 18.23 \\
Av. starter intake (kg/d) & 0.619 & 0.503 & 0.447 \\
Cost of starter (L.E./d) & 3.095 & 2.515 & 2.235 \\
Av. BH intake (kg/d) & 0.425 & 0.343 & 0.258 \\
Cost of BH (L.E./d) & 0.808 & 0.652 & 0.490 \\
Av. RS intake (kg/d) & 0.227 & 0.193 & 0.141 \\
Cost of RS (L.E./d) & 0.125 & 0.106 & 0.078 \\
Av. daily feeds cost (L.E.) & 17.31 & 19.17 & 21.04 \\
daily gain (kg) & 0.502 & 0.570 & 0.558 \\
Price of daily gain (L.E.) & 34.14 & 38.76 & 37.94 \\
Economic efficiency (\%)* & 197.2 & 202.2 & 180.3 \\
\hline * Economic feed efficiency $=$ Price of the weight gain (L.E.)/daily feed cost (L.E.)x100. Price (L.E./ton) of milk replacer \\
powder, starter, berseem hay and rice straw was 18000, 5000, 1900 and 550, while price of each kg gain was 68 L.E. \\
according to marketing price at 2017. & &
\end{tabular}

\section{CONCLUSION}

Use milk replacer at a rate of $10 \%$ of calves live body weight improved productive performance with normal health and cost effective use for suckling calves, compared with other rates. This may help farmers to keep up and care suckling buffalo calves and not sell them and such regime could help to alleviate the problem of milk and beef shortage in Egypt.

\section{REFERENCES}

AOAC (1995). Association of Official Analytical Chemists. Official Methods of Analysis. $15^{\text {th }}$ Ed. Arlington, VA, USA.

Abd Ellah, M.R.; M.I. Hamed; D.R. Ibrahim and H.Z. Rateb (2014). Serum biochemical and haematological reference intervals for water buffalo (Bubalus bubalis) heifers. J. of the South African Vet. Assoc., 85(1): 962.

Abdullah, M.; Iqbal, M. Zeeshan; M. Saadullah; A. Haque; K.Javed; M. Abdul Jabbar and A.Tauseef (2013). Comparative performance of calves fed milk and/or milk replacer supplemented with calf starter up to weaning age in Nili-Ravi Buffaloes. Buffalo Bulletin, Vol. 32 (Special Issue 2): 874-877. 
Aquino, D.L.; M.C.C.; Maroon; A.F. Abesamis Jr and M.V. Rosario (2008). Utilization of milk substitute in rearing buffalo calf. Philippine J. Vet. Anim. Sci., 34(1): 33-42.

Bach. A. A.; J. Gimenez; L. Juaristi and J. Anedo (2007). Effect of physical from of a starter for dairy replacement calves on feed intake and performance. J. Dairy Sci., 90: 2028-2033.

Baldwin, R. L.; K. R.McLeod; J. L. Klotz and R. N. Heitmann (2004). Rumen development, intestinal growth and hepatic metabolism in the pre- and post-weaning ruminant. J. Dairy Sci. 87(E. Suppl.):E55E65.

Baker, R. D. and J. M. Barker (1978). Milk-fed calves. 4. The effect of herbage allowance and milk intake upon herbage intake and performance of grazing calves. J. Agric. Sci. (Camb.) 90:31.

Baker, R. D.;Y. L. P. Le Du and J. M. Barker (1976). Milk-fed calves. 1. The effect of milk intake upon the herbage intake and performance and grazing calves. J. Agric. Sci. (Camb.) 87:187.

Bartles, H.; M. Bohmer and C. Heirli (1972). Serum kreatinin bestimmung enteiweissen. Clin. Chem. Acta, $37: 193$.

Bartlett, K.S.; F. K. McKeith; M. J. VandeHaar; G. E. Dahl and J. K. Drackley (2006). Growth and body composition of dairy calves fed milk replacers containing different amounts of protein at two feeding rates. J. Anim. Sci., 84:1454-1467.

Bascom, S.A.; R. E. James; M. L. McGilliard and M. E. Van Am-burgh (2007). Influence of dietary fat and protein on body composition of Jersey bull calves. J. Dairy Sci., 90:5600-5609.

Bhatti, S.A.; A. Ali; H. Nawaz; D. McGill; M. Sarwar; M. Afzal; M .S. Khan; Amer M.A. Ehsanullah; R. Bush;P. C. Wynnand and H. M. Warriach (2012). Effect of pre-weaning feeding regimens on postweaning growth performance of Sahiwal calves. Journal of Applied, 6 (8):1231.

Bhatti, S. A.; J. G. P. Bowman; J. L. Firkins; A. V. Grove and C.W. Hunt (2008). Effect of intake level and alfalfa substitution for grass hay on ruminal kinetics of fiber digestion and particle passage in beef cattle. J. Anim. Sci., 86:134-145.

Blome, R.M.; J.K. Drackley; F. K. McKeith; M. F. Hutjens and G. C. McCoy (2003). Growth, nutrient utilization and body composition of dairy calves fed milk replacers containing different amounts of protein. J. Anim. Sci., 81:1641-1655.

Broesder, J. T.; J. B. Judkins; L. J. Krysl; S. A. Gunter and R. K. Barton (1990). Thirty or sixty percent milk replacer reduction for calves: Effects on alfalfa hay intake and digestibility, digestive kinetics and ruminal fermentation. J. Anim. Sci., 68:2974-2985.

Brown, E.G.; M. J. VandeHaar; K. M. Daniels; J. S. Liesman; L. T. Chapin; D. H. Keisler and M. S. Weber Nielsen (2005). Effect of increasing energy and protein intake on body growth and carcass composition of heifer calves. J. Dairy Sci., 88:585-594.

Bull, R.C.; D. O. Everson; D. P. Olson; K. W. Kelly; S. Curtis and G.Tzou (1991). Concentration of serum constituents in cold-stressed calves from heifers and inadequate protein and (or) energy. Journal of Animal Science, 69: 853-863.

Cabaud, P.G.; F. Wreblewski and V. Rauggiero (1958). Colorimeteric measurement of LDH acitivity of body fluids. Am. J. Clin. Pathol., 30: 234.

Cowles, K.E.; R. A. White; N. L.Whitehouse and P. S. Erickson (2006). Growth characteristics of calves fed an intensified milk replacer regimen with additional lactoferrin. J. Dairy Sci., 89:4835-4845.

Diaz, M.C.; M. E. Van Amburgh; J. M. Smith; J. M. Kelsey and E.L. Hutten (2001). Composition of growth of Holstein calves fed milk replacer from birth to 105-kilogram body weight. J. Dairy Sci., 84:830-842.

Doumas, B.; W.Wabson and H. Biggs (1971). Albumin standards and measurements of serum with bromocresol green. Clin. Chem. Acta, 31: 87.

Duncan, D. B. (1955). Multiple range and multiple F test. Biometrics, 11: 1-42.

FAO (1998). Production year book, Vol. 52 FAO Publ., Rome. Italy, pp 35. 


\section{Shahin et al.}

FAO (2004). Food and Agricultural Organization, 2004, FAO-STAT, Global Livestock Production and Health Atlas. Animal Production and Health Division, Rome, Italy Available at: (http://www.fao.org/ag/aga/glipha/in-dex.jsp).

Foote, M.R.; B. J. Nonnecke; W. R. Waters; M. W. Palmer; M.A. Fowler; B. L. Miller and D. C. Beitz (2004). Dietary protein and energy and the adaptive immune response of milk-replacer fed dairy calves. J. Dairy Sci., 87(Suppl. 1): 406. (Abstr.)

Fox, D. G.; C. J. Sniffen and J. D. O’Connor1 (1988). Adjusting nutrient requirements of beef cattle for animal and environmental variations. J. Anim. Sci. 66:1475-1495.

Friedewald, W.T.; R. I. Levy and D. S. Fredrickson (1972). Estimation of the concentration of low-density lipoprotein cholesterol in plasma, without use of the preparative ultracentrifuge. Clin. Chem., 18: 499.

Gerrits, W. J. J.; G. H. Tolman; J. W. Schrama; S. Tamminga; M.W. Bosch, and M. W. A. Verstegen (1996). Effect of protein and protein-free energy intake on protein and fat deposition rates in preruminant calves of 80 to $240 \mathrm{~kg}$ live weight. J. Anim. Sci.74:2129.

Hammon, H.M. and J. W. Blum (1998). Metabolic and endocrine traits of neonatal calves are influenced by feeding colostrum for different durations or only milk replacer. J. Nut., 128: 624-632.

Harvey, J.W. (1997). The erythrocyte: physiology, metabolism, and biochemical disorders. In: Clinical biochemistry of domestic animals, J.J. Kaneko, J.W. Harvey \& M.L. Bruss, (Ed.), pp. 157-203, Academic Press , ISBN 0-12-396305-2, San Diego, California.

Henry, R.J. (1964): Proteins. In: Clinical Chemistry Principles and Technics, $1^{\text {st }}$ ed., Chapter 11, pp.173-253, Harper \& Row Publishers, New York.

Huber, J. T. ; A. G. Silva; O. F. Campos and C. M. Mathiew (1984). Influence of feeding different amount of milk on performance, health and absorption capability of baby calves. J. Daily Sci., 67: 2957-2963.

Hulbert, L.; S. Trombetta; J. Noel; S.Moisá; S. Montgomery; G. Hanzlicek and B. Bradford (2014). Effects of milk, pasteurized milk, and milk replacer on health and productivity of dairy calves. Kansas Agri. Exp. St. Res. Rep., Iss.(2). (https://doi.org/10.4148/2378-5977.3110).

Jasper, J. and D. M. Weary (2002). Effects of ad libitum milk intake on dairy calves. J. Dairy Sci., 85:30543058.

Ježek, J.; T. Malovrh. and K. Martina (2012). Serum immunoglobulin (IgG, IgM, IgA) concentration in cows and their calves. 20th Int. Symp. "Animal Science Days", Kranjska gora, Slovenia, Sept. $19^{\text {th }}-21^{\text {st }}$.

Kearl, L.C. (1982). Nutrient requirements of ruminants in developing countries. Utah State Univ., Logan.

Killingsworth, L.M. and J. Savory (1972). Manual Nephelometric Methods for Immunochemical determination of immunoglobulins IgG, IgA and IgM. Clin. Chem., 18 (4): 335-339.

Krishnamoorthy, U and J. Moran (2011). Rearing young ruminants on milk replacers and starter feeds, FAO, united Nations, Rome,13, ISSN, 1810.

Kuehn, C.S.; D. E. Otterby and J. G. Linn (1994). The effect of dietary energy concentration on calf performance. J. Dairy Sci., 77:2621-2629.

Kumar, R.; J. Mohanarao; D. Arvin and S. K. Atreja (2011). Freeze-thaw induced genotoxicity in buffalo (Bubalus bubalis) spermatozoa in relation to total antioxidant status. Mol. Biol. Rep., 38: 1499-1506.

Lee, H.J.; M. A. Khan; W. S. Lee; H. S. Kim; K. S. Ki; S. J. Kang; T. Y. Hur; M. S. Khan and Y. J. Choi (2008). Growth, blood metabolites and health of Holstein calves fed milk replacer containing different amounts of energy and protein. Asian-Australians J. Anim. Sci., 21: 198.

Logue, D. N. and C. Mayne (2014). Welfare-positive management and nutrition for the dairy herd: A European perspective. Vet. J., 199:31-38.

Lorenz, I.; J. F. Mee; B. Earley and S. J.More (2011). Calf health from birth to weaning. I. General aspects of disease prevention. Irish Vet. J., (64): 10.

Mc Gowan, M.W.; J. D. Artiss; D. R. Strandoergh and B. Zak (1983): Aperoxidase-Coupled method for the colorimetric determination of serum triglycerides. Clin. Chem., 29: 538-542. 
McDonald, P.; R. A. Edwards; J. F. Greenhalgh; C. A. Morgan; L. A. Sinclair and R. G. Wilkinson (2010). Animal Nutrition. $7^{\text {th }}$ edition, Longman Inc. New York, Chapter 10: Evaluation of foods: Digestibility 238-243.

Moms, C.A. and J. W. Wilton (1976). Influence of body size on the biological efficiency of cows: A review. Can. J. Anim. Sci., 56:613.

NRC (2001). National Research Council. Nutrient Requirements of Dairy Cattle $7^{\text {th }}$ rev. ed. National Academy Press, Washington, DC, USA.

Niaz, B.; A. Khan; M. T. Javed; A. Hussain and K. M. Ahmad (2000). Haematological studies in induced buffalo neonatal calf diarrhea with enteropathogenic E. Coli. Pakistan Vet. J., 20 (2): 85-89.

Nigm, A.A. (1996). Characterization of the Egyptian buffalo. International Symposium on Buffalo Resource and Production System. 14-17 October, Anim. Prod. Res. Inst. Cairo, Egypt.

Quigley, J.D.; T. A. Wolfe and T. H. Elsasser (2006). Effects of additional milk replacer feeding on calf health, growth and selected blood metabolites in calves. J. Dairy Sci., 89: 207-216.

Reitman, A. and S. Frankel (1957). Colorimetric method for the determination of serum glutamicoxaloacetic and glutamic-pyruvate transaminase. Amer. J. Clin. Path., 28: 56.

Richmond, W. (1973). Preparation and properties of a cholesterol oxidase from Nocardia sp. and its application to the enzymatic assay of total cholesterol in serum. Clin. Chem., 19: 1350-1356.

Salama, M.A. and M.M. Mohy El-Deen (1999). Weaning buffalo calves on basis of dry matter intake as percentage of birth weight. Buffalo Journal, 2:165.

Saunders, W.B. (1995): Tietz NWeditor. Clinical Guide to Laboratory Tests. $3^{\text {rd }}$ ed. Philadelphia. 612.

Smith, J.M.; M. E. Van Amburgh; M. C. Diaz; M. C. Lucy, M.C. and D. E. Bauman (2002). Effect of nutrient intake on the development of the somatotropic axis and its responsiveness to GH in Holstein bull calves. J. Anim. Sci., 80:1528-1537.

Soberon, F. and M. E. Van Amburgh (2012). The effect of nutrient intake from milk or milk replacer of preweaned dairy calves on lactation milk yield as adults. J Anim. Sci., 2:706.

SPSS (2010). Statistical Package for Social Science. Version 15, SPSS Inc. Chicago, USA.

Trinder, P. (1969). Determination of blood serum glucose. Ann. Clin. Biochem., 6:24.

Warner, R. G. and W. P. Flatt (1965). Physiology of digestion in ruminant. London UK: Butterworths Pub. Co.

Weary, D.M.; J. M. Huzzey and M. A. G. Keyserlingk (2009). Board-invited review: Using behavior to predict and identify ill health in animals. J. Anim. Sci., 87: 770-777.

Wright, I. A. and A. J. F. Russel (1987). The effect of sward height on beef cow performance and on the relationship between calf milk and herbage intakes. Anim. Prod., 44:363-370.

Wyatt, R. D.; M. B. Gould, and R. Totusek (1977). Effects of single vs simulated twin rearing on cow and calf performance. J. Anim. Sci., 45:1409-1414.

Yang, B.; B. He; S. S. Wang; J. X. Liu and J. K. Wang (2015). Early supplementation of starter pellets with alfalfa improves the performance of pre- and post-weaning Hu lambs. J. Anim. Sci., 93: 4984- 4994.

Young, D.S. (1995). Effects of drugs on clinical laboratory tests. $4^{\text {th }}$ ed. Washington, DC, American Association for Clinical Chemistry Press.

ZHAO Heng-bo; Luo Hai-Ling; ZHU H ong; XU Yong Feng; LIU Kai and ZHANG Xiao- hong (2007). Effect of fibrolytic enzymes on gastrointestinal morphological structure in Kids. Chinese J. of Anim. and Vet. Sci., 2007-2010.

Zicarelli, L. (2006). Buffalo calf weaning and production. In: Proceeding $3^{\text {rd }}$ Simposio Bufalos de las Americas $-2^{\text {nd }}$ Simposio de bufalos de bufalos Europa-America, Medellin, Columbia, 80-86.

Zollner, N. and K. Kirsch (1962): Determination of total lipids. Z. Ges. Exp. Med., 135:545. 
الأداء الإنتاجي لعجول الجاموس المغذاة على معدلات مختلفة من بديل اللبن

\author{
جمال فاروق شاهين ، منى السيد فرج ، E.A. El-Bltage ، و وائل محم وفا ، محمد عبد الحكيم كثثك و صلاح ابراهيم عطية

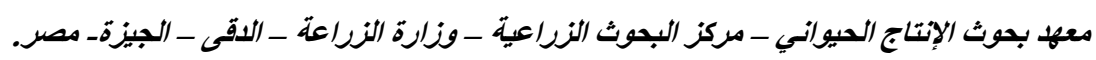

تهلف هذه الدراسة الى تقييم الأداء الإنتاجي و الكفاءة الغذائية والاقتصادية قبل وبعد الفطام لعجول الجاموس المغذاة على بديل اللبن بنسب

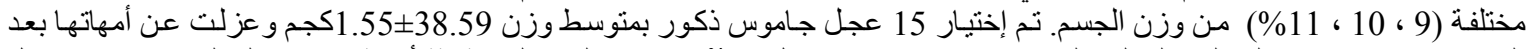

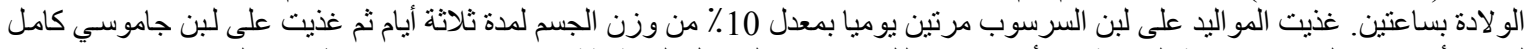

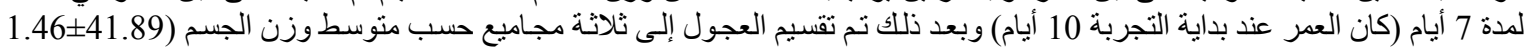
كجم) عند بداية فترة المعاملة.

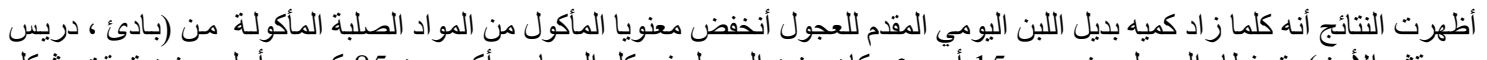

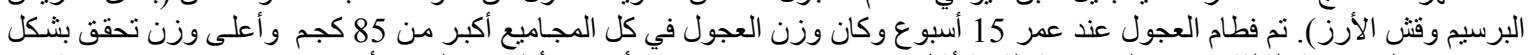

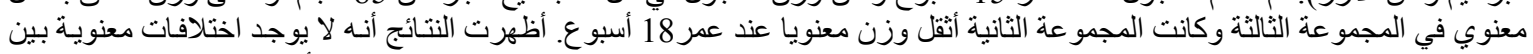

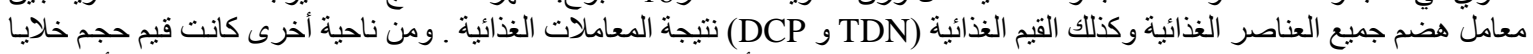

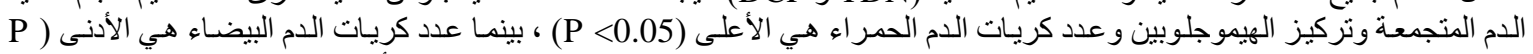

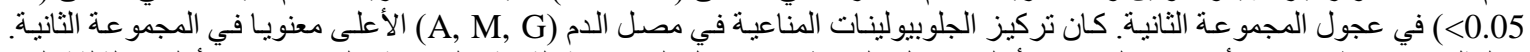

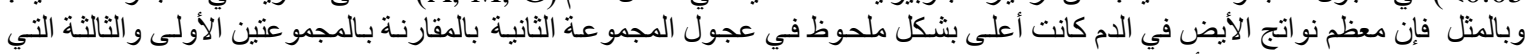

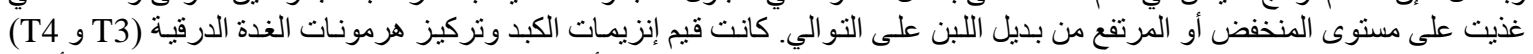

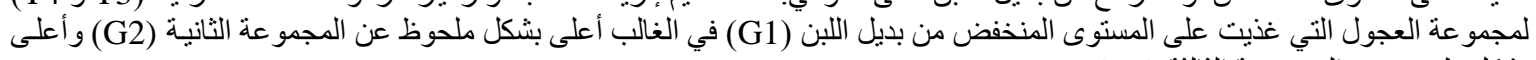
بشكل طفيف عن المجمو عة الثالثة (G3).

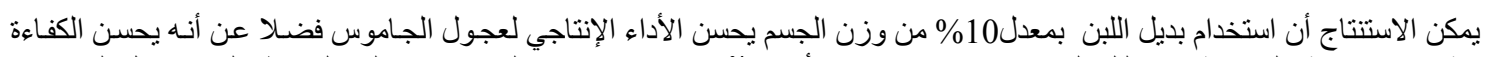

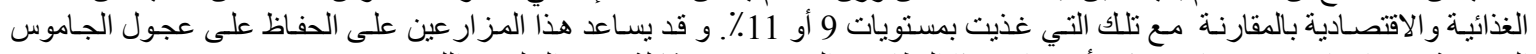
الرضيعة ور عايتها و عدم بيعها ، ويمكن أن يساعد هذا النظام في التخفيف من مثكلة نقص الحليب و اللحوم في مصر. 